\title{
A mountain of millipedes IV: Species of Prionopetalum Attems, 1909, from the Udzungwa Mountains, Tanzania. With notes on "P." fasciatum (Attems, 1896) and a revised species key (Diplopoda, Spirostreptida, Odontopygidae)
}

\author{
Henrik ENGHOFF \\ Natural History Museum of Denmark, University of Copenhagen, Universitetsparken 15, \\ DK-2100 Copenhagen Ø, Denmark. Email: henghoff@snm.ku.dk \\ urn:1sid:zoobank.org:author:FB09A817-000D-43C3-BCC4-2BC1E5373635
}

\begin{abstract}
Two species of the genus Prionopetalum Attems, 1909, are recorded from the Udzungwa Mountains: P. asperginis sp. nov. and P. kraepelini (Attems, 1896). Prionopetalum stuhlmanni Attems, 1914, is synonymized under P. kraepelini. Odontopyge fasciata Attems, 1896, is transferred from Prionopetalum to Aquattuor Frederiksen, 2013, and new illustrations are given. A new illustrated key to species of Prionopetalum is provided.
\end{abstract}

Keywords. Eastern Arc, taxonomy, new species.

Enghoff H. 2016. A mountain of millipedes IV: Species of Prionopetalum Attems, 1909, from the Udzungwa Mountains, Tanzania. With notes on "P." fasciatum (Attems, 1896) and a revised species key (Diplopoda, Spirostreptida, Odontopygidae). European Journal of Taxonomy 215: 1-23. http://dx.doi.org/10.5852/ejt.2016.215

\section{Introduction}

This is the fourth in a series of articles about the millipedes, especially the endemic Afrotropical family Odontopygidae, of the Udzungwa Mountains, Tanzania. For general information on the Odontopygidae and the Udzungwa Mountains see the first article in the series (Enghoff 2014; see also Enghoff \& Frederiksen 2015 and Enghoff 2016).

Unlike many other genera of Odontopygidae, Prionopetalum Attems, 1909, is well-defined and easily recognized since the monumental work of Kraus (1960). It is also one of the few odontopygid genera which have been subject of a subsequent comprehensive review (VandenSpiegel \& Pierrard 2009). In both of these treatments, a key to species is included, in German and French, respectively. Considering that the vast majority of species of Prionopetalum live in East Africa, where English is much more widely understood than German and French, a key in English is provided here.

Two species of Prionopetalum, one of them new, have been collected in the Udzungwa Mountains and are (re)described here. Prionopetalum stuhlmanni Attems, 1914, is shown to be the same species as P. kraepelini (Attems, 1896). Furthermore, Odontopyge fasciata Attems, 1896, which had been included, with some doubts, in Prionopetalum by previous authors, is shown to belong in the genus Aquattuor Frederiksen, 2013. With these adjustments, Prionopetalum now contains 23 described species. 


\section{Material and methods}

The bulk of the material for this article comes from the zoological collections of the Natural History Museum of Denmark, University of Copenhagen (ZMUC). These specimens were collected during field trips by ZMUC staff and students. Additional specimens from other institutions (see below) were also examined. All specimens are kept in $70 \%$ alcohol.

Specimens were examined in alcohol under a stereo microscope. Specimens for scanning electron microscopy (SEM) were transferred to $96 \%$ ethanol, then to acetone, air-dried, mounted on aluminium stubs or on pieces of flexible aluminium tape and in turn mounted on stubs, coated with platinumpalladium and studied in a JEOL JSM-6335F scanning electron microscope.

As in previous articles in this series, only adult males are considered. A total of 22 adult males of the two Udzungwa species were examined. Figure 1 shows the Udzungwa localities where Prionopetalum specimens were collected.

See Enghoff (2014) for the description standards used.

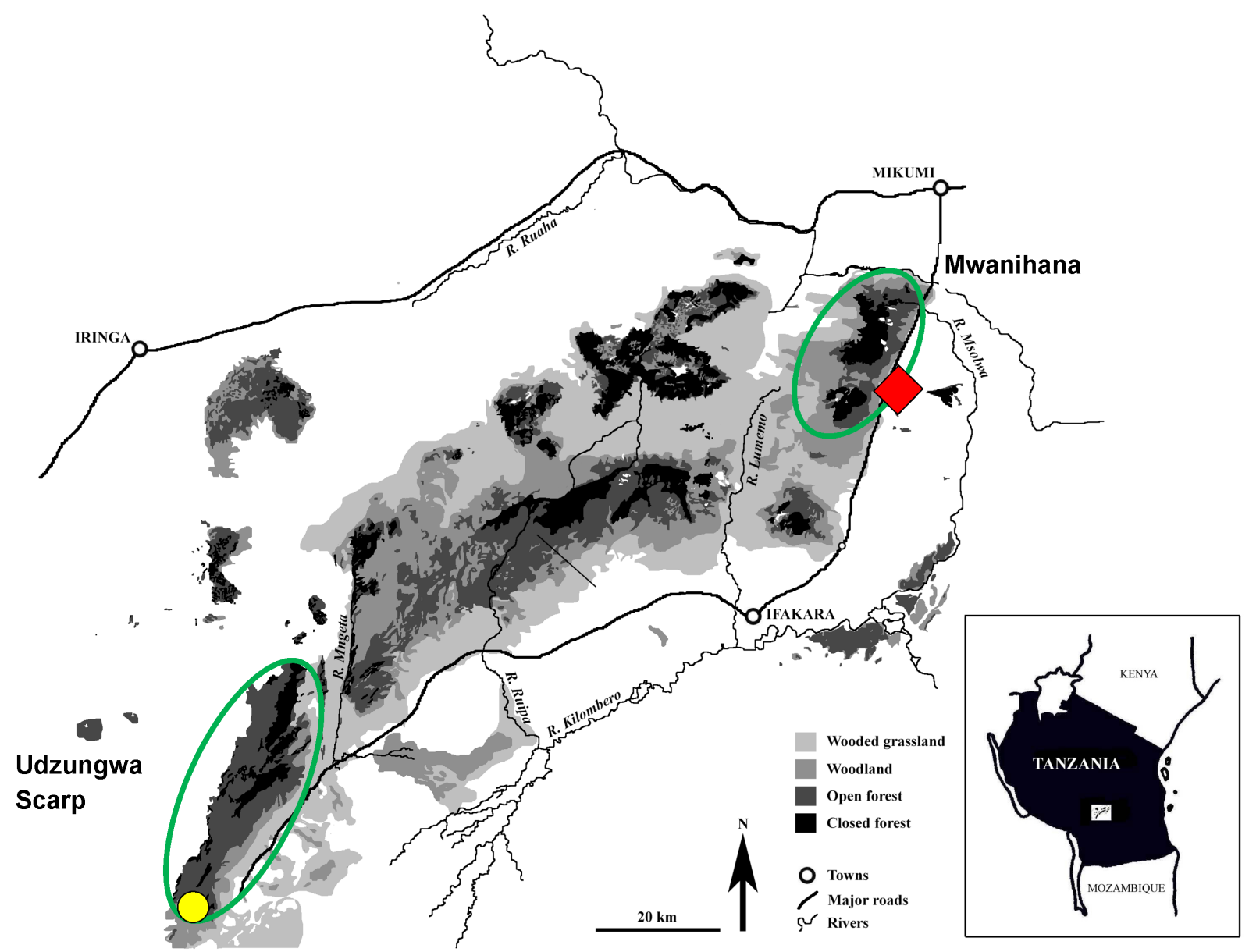

Fig. 1. Map of the Udzungwa Mountains, showing the collecting localities for Prionopetalum asperginis sp. nov. (yellow dot) at the southern extremity of the Udzungwa Scarp Forest Reserve and for P. kraepelini (Attems, 1896) (red diamond) at the eastern edge of the Mwanihana Forest Reserve. Based on fig. 1 in Marshall et al. (2010). 


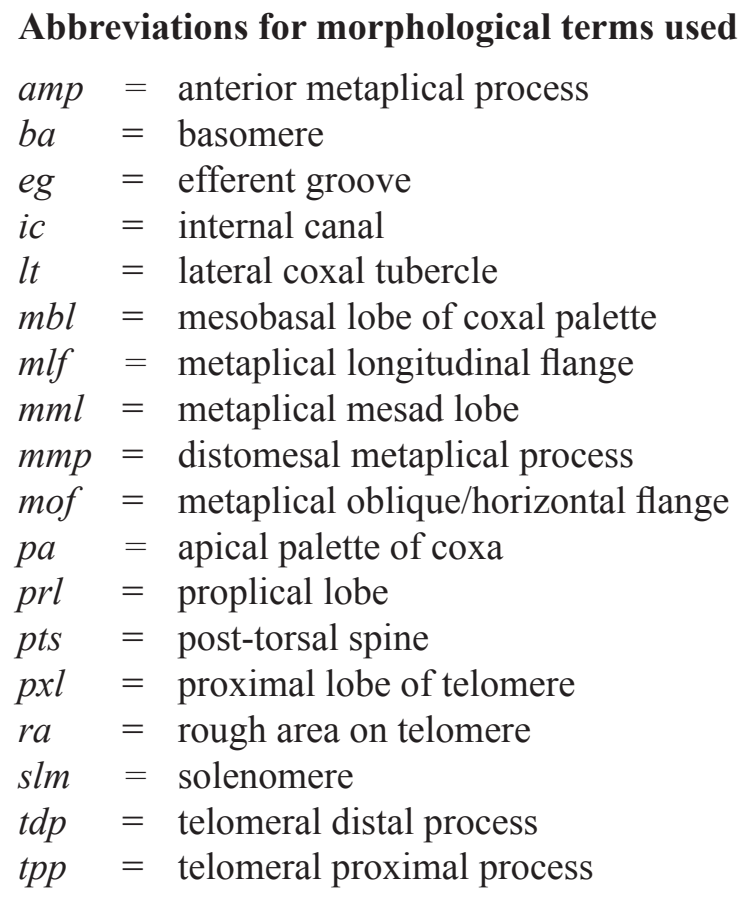

Other abbreviations used in the text

asl $=$ above sea level

NHMW $=$ Naturhistorisches Museum, Vienna

$\mathrm{VMNH}=$ Virginia Museum of Natural History

ZMUC = Natural History Museum of Denmark (Zoological Museum)

$\mathrm{ZMUH}=$ Zoologisches Museum der Universität Hamburg

\title{
Results
}

\author{
Class Diplopoda Blainville-Gervais, 1844 \\ Order Spirostreptida Brandt, 1833 \\ Family Odontopygidae Attems, 1909 \\ Subfamily Archepyginae Manfredi, 1939 \\ Tribe Prionopetalini Hoffman, 1991
}

Genus Prionopetalum Attems, 1909

Prionopetalum Attems, 1909: 51.

Type species: Prionopetalum serratum Attems, 1909, by original designation.

Unlike many other genera of Odontopygidae, Prionopetalum is well-defined and quite homogeneous, not only in non-sexual characters, but also in gonopod structure.

\section{Diagnosis}

(Modified after Kraus 1960 and VandenSpiegel \& Pierrard 2009, excluding some non-gonopodal characters which were mentioned by these authors but which are of no diagnostic value.)

Prionopetalini in which the anal valves have a raised rim, a well-developed dorsal spine and sometimes a smaller ventral one; limbus with simple, pointed denticles (true of all species after removal of 
Table 1. Numbers of podous rings and body diameter of adult males of species of Prionopetalum. One has been subtracted from published "segment" numbers because these include the telson. None of the species are known to have apodous rings between the last podous ring and the telson.

\begin{tabular}{|c|c|c|c|}
\hline & No. of podous rings & Diameter (mm) & Source \\
\hline P. aculeatum & 66 & 5 & Attems 1914 \\
\hline P. asperginis sp. nov. & $60-65$ & $4.4-4.9$ & this study \\
\hline P. bifidum & $68-71$ & $5.6-6.8$ & VandenSpiegel \& Pierrard 2009 \\
\hline P. clarum & "nearly fourty-three" & 5.5 & Chamberlin 1927 \\
\hline P. cornutum & 63 & 3 & Kraus 1958 \\
\hline P. coronatum & 58 & 3.7 & Kraus 1958 \\
\hline P. dentigerum & 65 & 6.0 & this study ${ }^{1}$ \\
\hline P. etiennei & 60 & 2.5 & this study ${ }^{2}$ \\
\hline P. exaratum & 57 & 2.5 & Attems 1938 \\
\hline P. frundsbergi & 72 & 7.6 & this study ${ }^{3}$ \\
\hline P. fryeri & 65 & 6 & Turk 1956 \\
\hline P. glomeratum & 58 & 2.5 & Attems 1935 \\
\hline P. kraepelini & $61-65$ & $3.2-3.6$ & Attems 1896; this study \\
\hline P. lindi & $58-59$ & $3.3-3.8$ & VandenSpiegel \& Pierrard 2009 \\
\hline P. megalacanthum & 62 & 4.3 & Attems 1912 \\
\hline P. ndelei & $61-63$ & 4.2 & VandenSpiegel \& Pierrard 2009 \\
\hline P. pulchellum & 64 & 3.0 & Kraus 1960 \\
\hline P. serratum & $62-66$ & 5.6 & Attems 1909 \\
\hline P. suave & 62 & 5 & Attems 1896 \\
\hline P. tanganjikum & 92 & $?$ & Verhoeff 1941 \\
\hline P. tricuspis & 65 & 5.5 & Brolemann 1920 \\
\hline P. urbicolum & $61-64$ & 4.5 & Carl 1909 \\
\hline P. xerophilum & c. 60 & 4.5 & Carl 1909 \\
\hline
\end{tabular}

${ }^{1}$ P. dentigerum: diameter not provided by Verhoeff (1941). Values based on $\delta^{\lambda}$ from Tanzania, Pwani Region, Kisarawe District, Ruvu South Forest Reserve, $140 \mathrm{~m}$ asl, 6 ${ }^{\circ} 57^{\prime} 27^{\prime \prime}$ S, 38 $50^{\circ} 0^{\prime} 1^{\prime \prime}$ E, date unknown, leg. Frontier Tanzania, det. H. Enghoff (ZMUC).

${ }^{2}$ P. etiennei: diameter not provided by Demange (1982). Values based on ${ }^{\lambda}$ from Guinée-Bissau, Buba, 9-11 Jun. 1989, leg. A. van Harten \& M. Neves., det. H. Enghoff (ZMUC).

${ }^{3}$ P. frundsbergi: no published information. Values based on ${ }^{\lambda}$ from Kenya, Bushwackers near Kibwezi, 30 Dec. 1982, leg. C.C. Kinze et al., det. H. Enghoff (ZMUC).

"P." fasciatum, see below). Male legs with ventral soft pads on postfemur and tibia, except on anteriormost and posteriormost legs (true of all species after removal of " $P$." fasciatum, see below).

Gonopods. Coxal metaplica on its basal part with a large longitudinal mesad flange $(\mathrm{mlf})$, separated by a deep sinus from an oblique-horizontal sub-semicircular mesad flange (mof). Telopodite with a posttorsal ("femoral") spine (pts), but without a ("tibial") spine near the origin of the solenomere, divided into solenomere and telomere shortly after post-torsal narrowing. Solenomere $(\mathrm{slm})$ simple, whip-like, without outgrowths (exception: P. fryeri (Turk, 1956) with a short accessory branch at $c .2 / 3$ of the 
solenomere's length). Telomere with two characteristic processes: a variously shaped, often speciesspecific proximal process ( $t p p$ ) which projects at \pm right angles from the main telomere axis, and a long, slender distal process $(t d p)$ which is armed with a row of spines or thorns. (In the terminology of Kraus (1960), tpp is "eine hornartige Spitze oder auch eine entsprechende, schalige Lamelle", and $t d p$ is "der meist auffallende schlankere Distalabschnitt ..... gezackt oder bezahnt". For VandenSpiegel \& Pierrard (2009), tpp is a "processus basal du tarse".)

\section{Body size}

Published body diameters for adult males range from $2.5 \mathrm{~mm}$ (P. exaratum, $P$. glomeratum) to $6.8 \mathrm{~mm}$ (P. bifidum), but a male of $P$. frundsbergi in the ZMUC collection has a diameter of $7.6 \mathrm{~mm}$. Published numbers of podous rings range from 57 (P. exaratum) to 71 (P. bifidum), but the above-mentioned male of $P$. frundsbergi has 72 podous rings. Table 1 and Fig. 2 summarise the size information and give detailed information for the two Udzungwa species. One has been subtracted from published "segment" numbers because these have traditionally included the telson. Two records have been omitted: "nearly fourty-three" for P. clarum (Chamberlin, 1927) and 93 for P. tanganjikum Verhoeff, 1941 - the latter number is probably a lapsus calami.

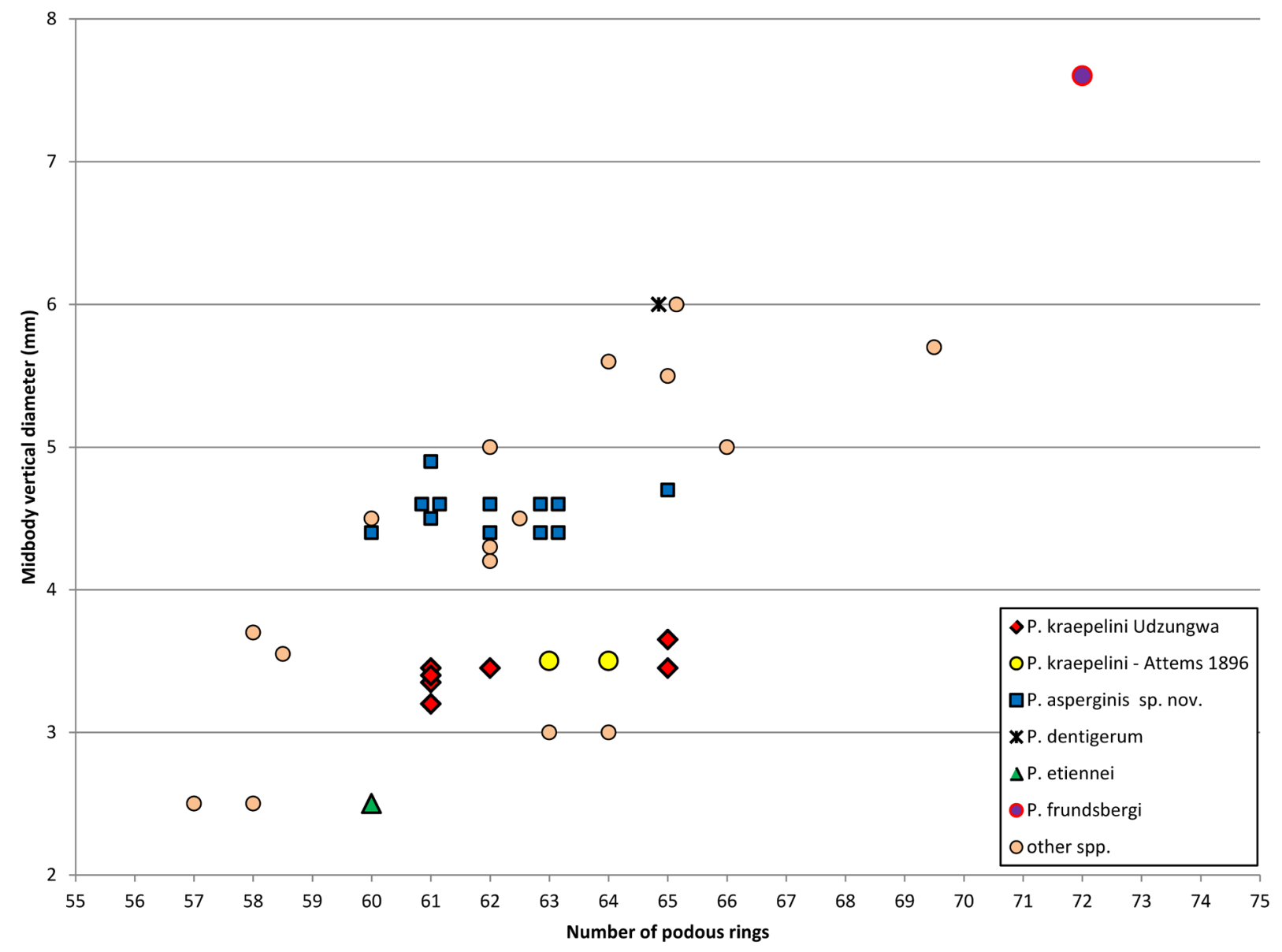

Fig. 2. Body size (body diameter / number of podous rings) of $\widehat{\partial}$ of Prionopetalum spp. Based on original measurements and data from the literature (see Table 1). For "other spp." the entries are median values of the intervals in Table 1.The report of "93 (1) Rumpfringen" (corresponding to 92 podous rings) for P. tanganjikum by Verhoeff (1941) has been omitted, as has Chamberlin's (1927) "nearly fourtythree" segments for P. clarum; both are regarded as quite unlikely and are probably erroneous. 


\section{Included species}

P. aculeatum Attems, 1914 - Somalia, Kenya

P. asperginis sp. nov. - Tanzania

P. bifidum VandenSpiegel \& Pierrard, 2009 - Tanzania

P. clarum (Chamberlin, 1927) - D.R. Congo

P. cornutum Kraus, 1958 - D.R. Congo

P. coronatum Kraus, 1958 - D.R. Congo

P. dentigerum Verhoeff, 1941 - Tanzania, Rwanda

P. etiennei Demange, 1982 - Gambia, Guinée-Bissau, Sénégal

P. exaratum (Attems, 1938) - D.R. Congo

P. frundsbergi (Attems, 1927) - Kenya, Tanzania

P. fryeri (Turk, 1956) - Malawi, Zambia

P. glomeratum Attems, 1935 - D.R. Congo

P. kraepelini (Attems, 1896) - Tanzania

P. lindi VandenSpiegel \& Pierrard, 2009 - Tanzania

P. megalacanthum Attems, 1912 - D.R. Congo, Rwanda

P. ndelei VandenSpiegel \& Pierrard, 2009 - Central African Republic

P. pulchellum Kraus, 1960 - Mozambique

P. serratum Attems, 1909 - Kenya, Tanzania

P. suave (Gerstäcker, 1873) - Tanzania

P. tanganjikum Verhoeff, 1941 - Tanzania

P. tricuspis Brolemann, 1920 - Kenya

P. urbicolum (Carl, 1909) - Tanzania

P. xerophilum (Carl, 1909) - Rwanda, Tanzania

Prionopetalum asperginis sp. nov. urn:Isid:zoobank.org:act:FE9E9A13-4D50-40E9-8B6D-3D40AEA0E1A2

Figs $3-4,9 \mathrm{~W}, 10 \mathrm{D}, 11 \mathrm{~K}$

\section{Diagnosis}

Differs from congeners by the combination of a laterally smooth gonopod coxa, a pointed apical mesad metaplical process subtended by a rounded mesad lobe, a simple, fingerlike proximal telomere process and a simple distal telomere process without secondary branches.

\section{Etymology}

The species is named after the recently discovered Kihansi spray toad, Nectophrynoides asperginis Poynton, Howell, Clarke \& Lovett, 1999; see "Distribution and habitat".

Material studied (total: 15 ふึ๙)

\section{Holotype}

TANZANIA: đđ Udzungwa Mts, Kihansi, 8²4' S, 36²1' E, “forest site”, Jun.-Aug. 1997, I. Zilihona leg. (ZMUC).

\section{Paratypes}

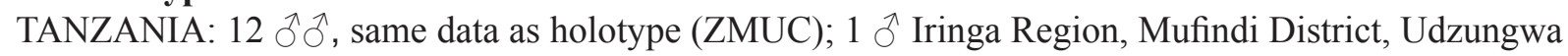

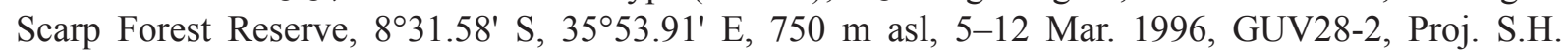
McKamey et al. leg. (ZMUC); 1 o Morogoro Region, Kilombero District, Lower Kihansi Project, Udagaji Gorge, 7 Nov. 1997, Jan Kielland leg. (VMNH). 

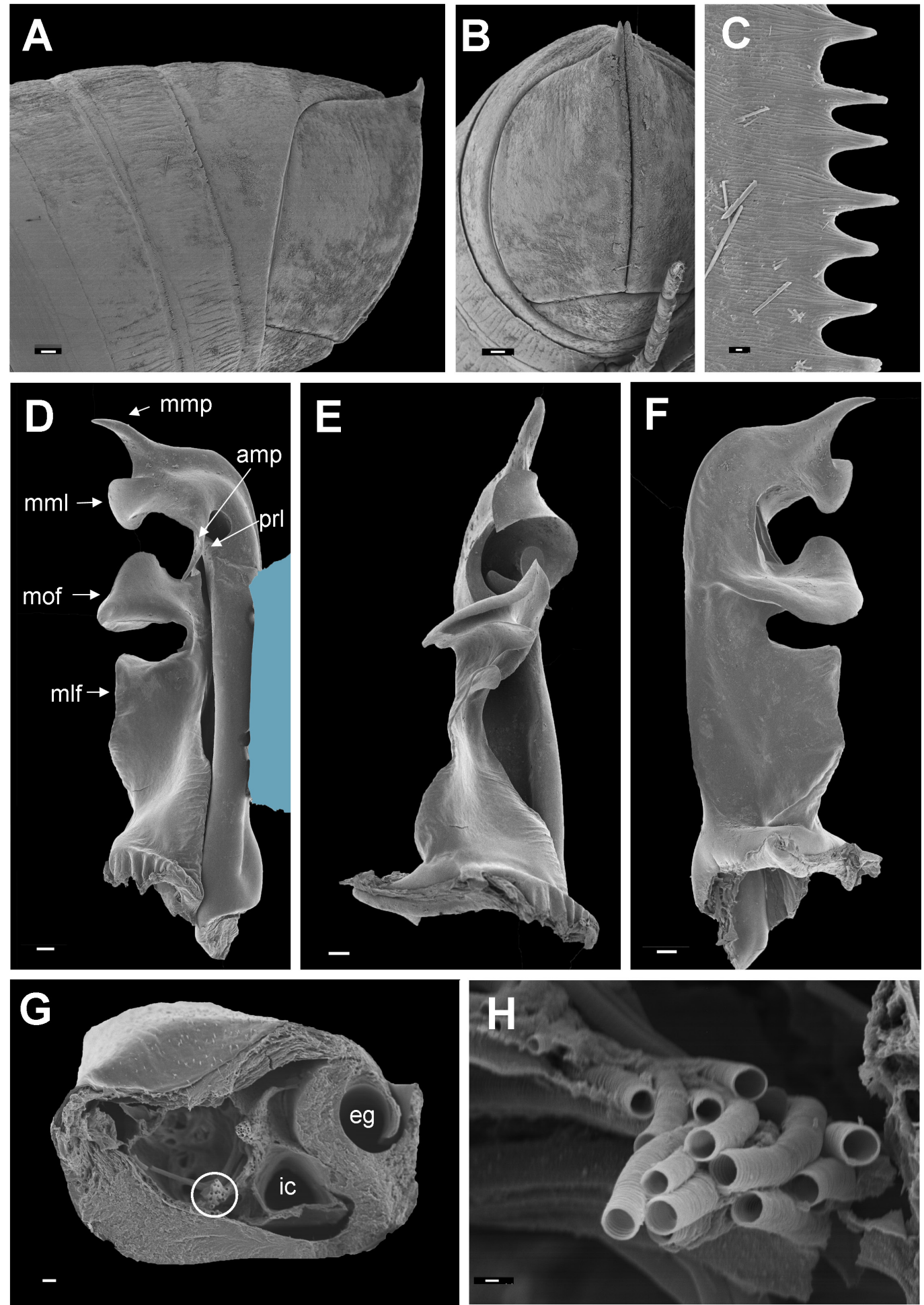

Fig. 3. Prionopetalum asperginis sp. nov., paratype from Kihansi, "forest site". A-B. Hind end. A. Lateral view. B. Posterior view. C. Limbus. D-F. Right gonopod coxa. D. Anterior view (light blue: mounting tape). E. Mesal view. F. Posterior view. G. Transverse section of right gonopod basomere (circle: bundle of tracheae). H. Cluster of tracheae next to internal canal. Abbreviations: amp $=$ anterior metaplical process; $e g=$ efferent groove; $i c=$ internal canal; $m l f=$ metaplical longitudinal flange; $m m l=$ metaplical mesad lobe; $m m p=$ distomesal metaplical process; $m o f=$ metaplical oblique/horizontal flange; $p r l=$ proplical lobe. Scale bars: A, B, D-F $=0.1 \mathrm{~mm} ; \mathrm{C}, \mathrm{H}=0.001 \mathrm{~mm} ; \mathrm{G}=0.01 \mathrm{~mm}$. 


\section{Type locality}

TANZANIA: Udzungwa Mts, Kihansi, $8^{\circ} 24^{\prime}$ S, 36²1' E.
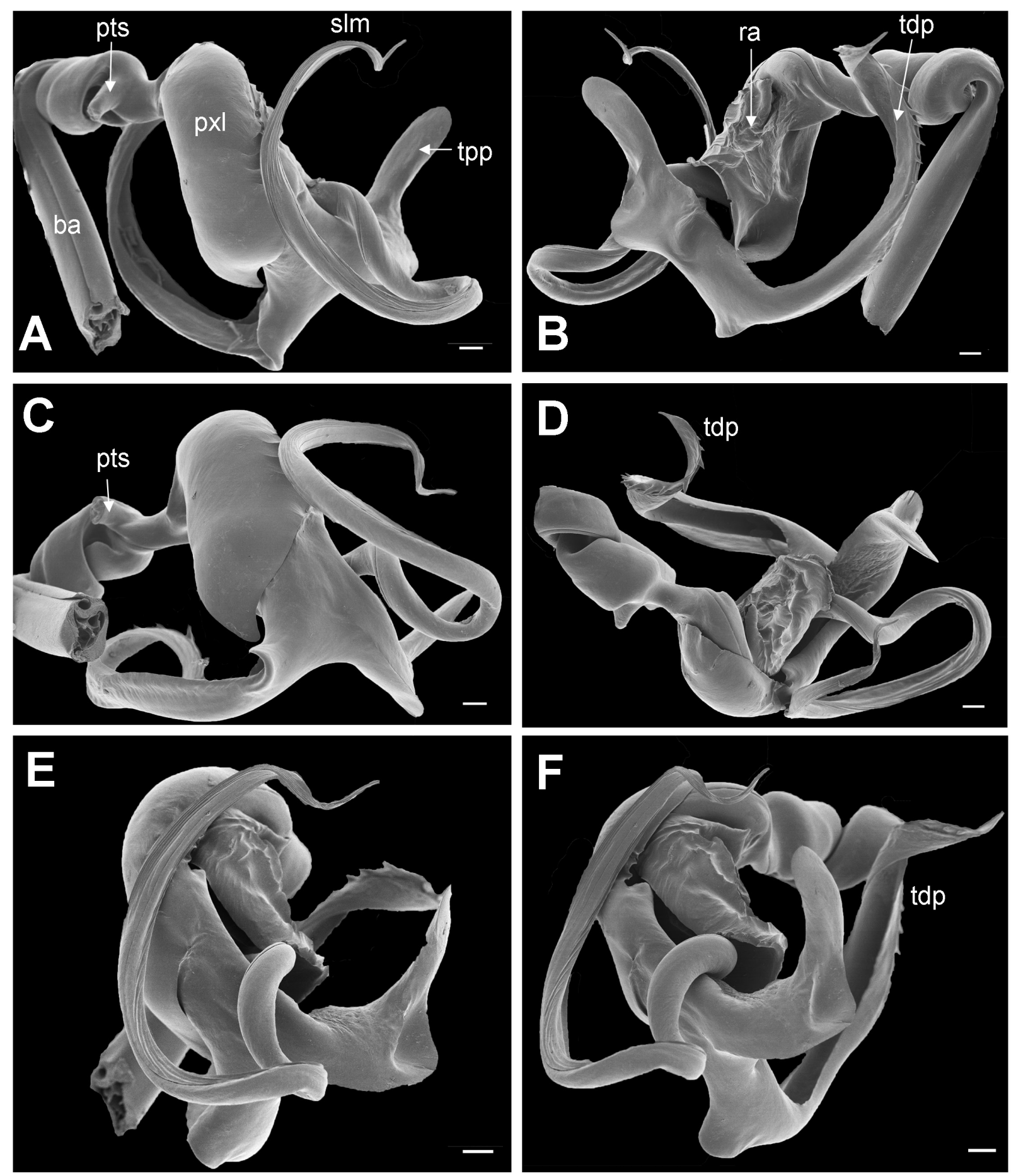

Fig. 4. Prionopetalum asperginis sp. nov., paratype from Kihansi, "forest site", right gonopod telopodite. A. Anterior and slightly mesal view. B. Posterior view. C. Basal view. D. Apical view. E. Apical-mesal view. F. Mesal and slightly posterior view. Abbreviations: $b a=$ basomere; $p t s=$ post-torsal spine (broken); $p x l=$ proximal lobe of telomere; $r a=$ rough area of telomere; $s l m=$ solenomere; $t d p=$ distal process of telomere; $t p p=$ proximal process of telomere. Scale bars $=0.1 \mathrm{~mm}$. 


\section{Description}

SizE. Length $c$. 61/2 cm, diameter 4.4-4.9 mm, 60-65 podous rings, no apodous rings in front of telson.

CoLour. After 18 years in alcohol almost uniform light brown. No lighter dorsal markings.

AnAl valves (Fig. 3A-B). Each with a long, pointed dorsal spine, no ventral spine, marginal rim raised, with 3 setae on very poorly demarcated tubercles.

LimBus (Fig. 3C). With triangular, almost equilateral, pointed lobes, external surface of lobes densely striate.

Male Legs. Postfemora and tibiae with large, soft pads, except on first four to five and several posteriormost leg pairs.

Gonopod COXA (Fig. 3D-F). Lateral margin almost straight, entirely smooth. Mesal margin of proplica straight, proplical lobe $(\mathrm{prl})$ in anterior view almost hidden behind apical expansion of metaplica. Basal part of metaplica with large longitudinal mesad flange $(\mathrm{mlf})$, separated by a deep sinus from an obliquehorizontal, sub-semicircular mesad flange (mof), apical part of metaplica expanded anteriad, forming a pointed process $(\mathrm{amp})$ covering proplical lobe, a rounded mesad lobe $(\mathrm{mml})$ and a slender disto-mesad process $(\mathrm{mmp})$.

GonOPOD TELOPODite (Fig. 4). A well-developed post-torsal spine ("femoral spine", pts) just before posttorsal narrowing (broken on illustrated specimen). Solenomere $(\mathrm{slm})$ simple, slender. Telomere with a large, proximal lobe $(p x l)$ and a rough area $(r a)$ on apical surface, further distally divided into two processes. Proximal telomere process (tpp) parallel-sided, apically rounded. Distal telomere process $(t d p)$ only slightly broader than solenomere, apically with one margin denticulate (Fig. 4F).

\section{Distribution and habitat}

Known only from the southern part of the Udzungwa Mts, Udzungwa Scarp Forest Reserve and the Kihansi area. The latter area has become famous because of the Kihansi spray toad, Nectophrynoides asperginis Poynton, Howell, Clarke \& Lovett, 1999, which occurred in the Kihansi area but is now regarded as extinct in the wild although a reintroduction programme was started in 2013 (IUCN SSC Amphibian Specialist Group 2015). Zilihona et al. (1998) described in detail the area where I. Zilihona collected her specimens. Altitudinal range 550-750 m asl (cf. Zilihona et al. 1998).

\section{Coexisting species}

The sample collected by I. Zilihona also contains another, much smaller odontopygid which will be described in a forthcoming paper.

\section{Remarks}

Fig. 3G shows a transverse section (= break) of the basal part (basomere, $b a$ ) of the gonopod telopodite. The picture clearly shows how the canal $(\mathrm{eg})$ that continues to the tip of the solenomere is formed as a groove near the surface. This canal has been supposed to be a sperm canal ("Samenrinne" of Kraus 1966, e.g., his figs 28-29), but considering that nothing is known about its function, the neutral term "efferent groove" is preferable (cf. Enghoff 2011). There is also what looks like an entirely internal canal (ic) which is accompanied by dense bundles of tubuli, probably tracheae (Fig. 3H), similar to those recently described by Reboleira et al. (2015) from the base of the vulva of a cambalid millipede. The extent and function of this canal is unknown. 
Prionopetalum kraepelini (Attems, 1896)

Figs 5-6, 9R, 11I

Odontopyge kraepelini Attems, 1896: 37.

Prionopetalum stuhlmanni Attems, 1914: 210. New synonymy

Odontopyge pardalis - Attems 1896: 39.

Prionopetalum pardalis - Attems 1909: 52.

Prionopetalum kraepelini-Attems 1914: 210.

Not Spirostreptus pardalis Gerstäcker, 1873.

\section{Diagnosis}

Differs from all congeners by the multi-cusped proximal telomere process (Fig. 6F).

Material studied (total: $9 \stackrel{\jmath}{\diamond}$ )

\section{Syntypes}

TANZANIA: $1 \AA$, 1 ㅇ, Mhonda (Unguru), 6 Sep. 1888, F. Stuhlmann leg. (ZMUH).

\section{Other material}

TANZANIA: 1 đ, Lewa (Usambara), 26 Apr. 1888, F. Stuhlmann leg., holotype of Prionopetalum stuhlmanni (ZMUH); 3 $\widehat{\jmath}$, Morogoro Region, Mang'ula, at Udzungwa Ecological Monitoring Centre,

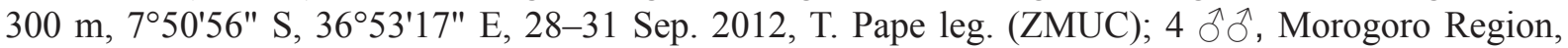
Udzungwa Mts, Udzungwa Ecological Monitoring Centre, Mang'ula, 0750'44.9" S, 36 53'28.2" E, 339 m, 18-20 Jan. 2014, T. Pape \& N. Scharff leg. (ZMUC).

\section{Type locality}

TANZANIA: Tanga Regon, Lushoto District, Usambara Mts, Lewa.

\section{Description (male)}

Size. Length $c$. $5 \mathrm{~cm}$, diameter 3.2-3.6 mm, 61-65 podous rings, no apodous rings in front of telson.

CoLour. After 1-3 years in alcohol head amber below antennae, blackish above; antennae blackish brown; collum blackish brown with light margins; body rings light brown below ozopores and immediately above, dorsally blackish brown with broad middorsal light spot; telson and legs medium brown.

ANAL VALVES. Each with a long, pointed dorsal spine and a much smaller ventral one, marginal rim raised, with 3 setae on very poorly demarcated tubercles.

LimBus (Fig. 5F). With triangular, almost equilateral, pointed lobes, external surface of lobes densely striate.

MaLe Legs. Postfemora and tibiae with large soft pads, except on first four to five and several posteriormost leg pairs.

GoNOPOD COXA (Fig. 5A-E). Lateral margin almost straight, entirely smooth or with a tiny tubercle $(l t)$ at c. $2 / 3$ height. Mesal margin of proplica straight, proplical lobe ( $\mathrm{prl}$ ) in anterior view hidden behind apical expansion of metaplica. Basal part of metaplica with large, longitudinal mesad flange $(\mathrm{mlf})$, separated by a deep sinus from an oblique-horizontal, two-lobed mesad flange (mof), apical part of metaplica expanded anteriad to form a process ( $\mathrm{amp}$ ) covering proplical lobe and produced disto-mesad into slender, apically bifid process ( $\mathrm{mmp}$ ). 

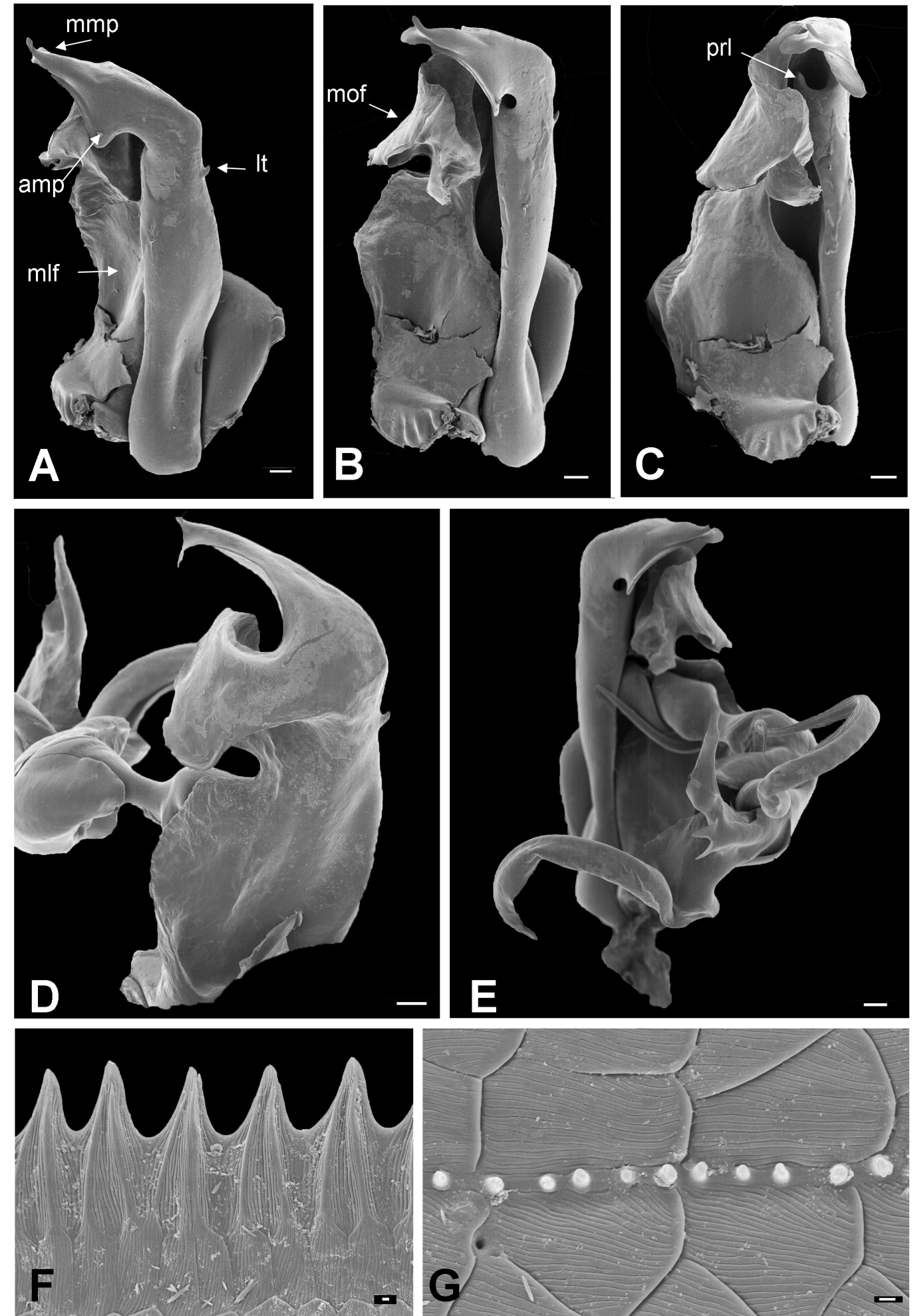

Fig. 5. Prionopetalum kraepelini (Attems, 1896), specimen from Mang'ula, $339 \mathrm{~m}$ asl. A-C. Right gonopod coxa. A. Anterior view. B. Anterior-mesal view. C. Mesal view. D-E. Left gonopod. D. Posterior view. E. Anterior-mesal view. F. Midbody-dorsal limbus. G. Row of intercalary microscutes with knobs, from midbody metazona. Abbreviations: $a m p=$ anterior metaplical process; $l t=$ lateral coxal tubercle; $m l f=$ metaplical longitudinal flange; $m m p=$ distomesal metaplical process; $m o f=$ metaplical oblique/horizontal flange; $p r l=$ proplical lobe. Scale bars: $A-E=0.1 \mathrm{~mm} ; \mathrm{F}-\mathrm{G}=0.001 \mathrm{~mm}$. 

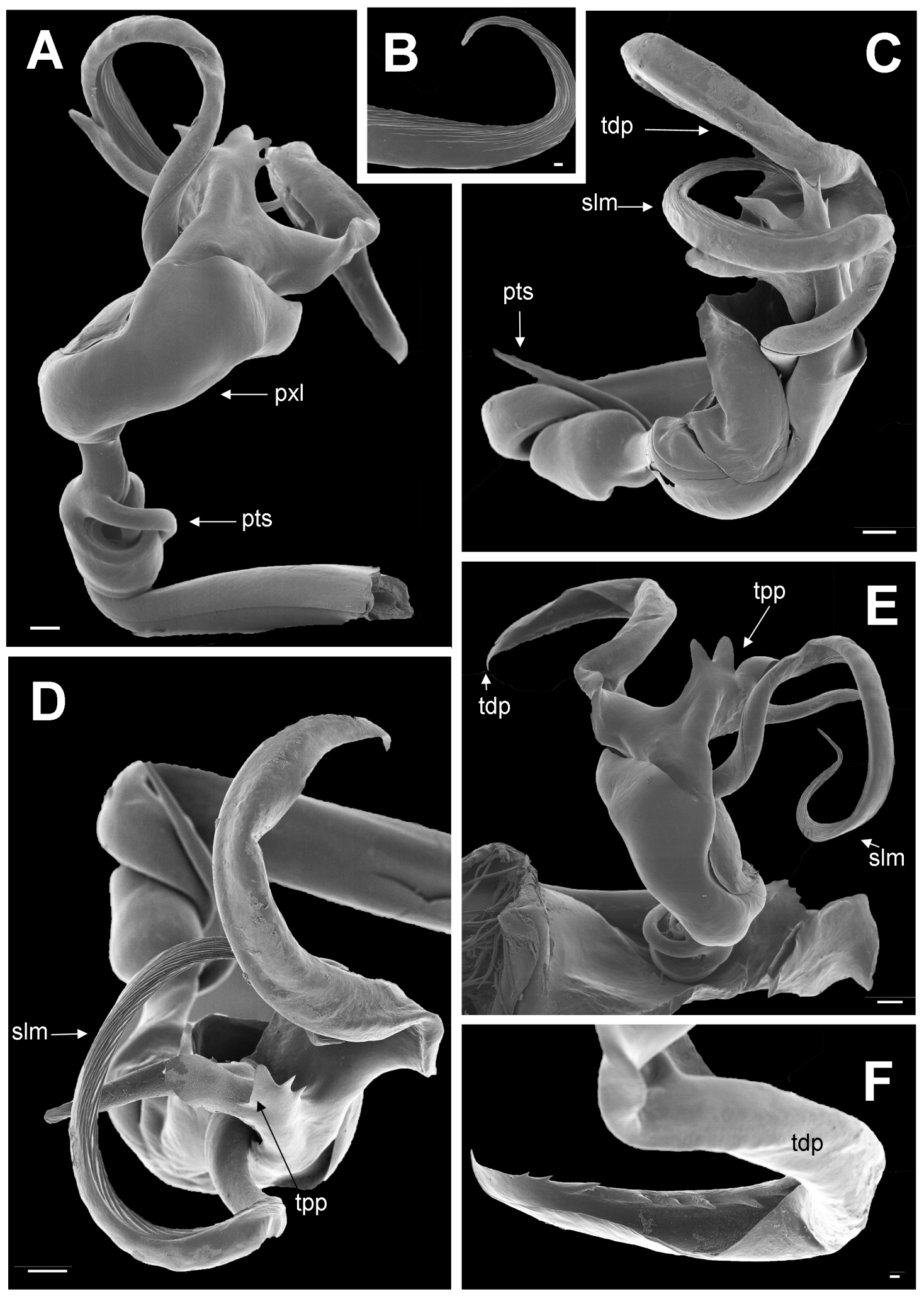

Fig. 6. Prionopetalum kraepelini (Attems, 1896), specimen from Mang'ula, $339 \mathrm{~m}$ asl. Gonopod telopodite. A, C-D, F. Right gonopod telopodite. A. Posterior view. C. Apical (ventral) view. D. Anterior view. F. Telomere distal process. B. Tip of left solenomere. E. Left gonopod, (posterior-) mesal view. Abbreviations: $p t s=$ post-torsal spine; $p x l=$ proximal lobe of telomere; $s l m=$ solenomere; $t d p=$ telomeral distal process; $t p p=$ telomeral proximal process. Scale bars: A, C-D, E = $0.1 \mathrm{~mm} ; \mathrm{B}, \mathrm{F}=0.2 \mathrm{~mm}$. 
GonOPOD TELOPODITE (Figs 5D-E, 6). A well-developed post-torsal spine ("femoral spine", pts) inserted just before post-torsal narrowing. Solenomere $(\mathrm{s} / \mathrm{m})$ simple, slender. Telomere with a large, proximal lobe $(p x l)$. Proximal telomere process (tpp) elaborate, with a longitudinal 3-5-dentate flange and a slender apical process, in certain views (Fig. 5E) recalling the head profile of cartoon character Woody Woodpecker. Distal telomere process $(t d p)$ only slightly broader than solenomere, apically with one margin denticulate (Fig. 6F).

\section{Distribution and habitat}

In addition to the newly collected material from the Udzungwa Mts, Udzungwa Ecological Monitoring Centre, Mang'ula (http://www.udzungwacentre.org/) at 300-339 m asl, O. kraepelini has been recorded from several other sites, all in Tanzania: Morogoro Region, Mhonda (Nguru) (type locality); Tanga Region, Lushoto Distr. Usambara Mts, Lewa (type locality of P. stuhlmanni); Arusha Region, Arusha District, near Lake Babati; Dar es Salaam (the latter two records by VandenSpiegel \& Pierrard 2009).

\section{Coexisting species}

At Mang'ula, P. kraepelini was collected together with another odontopygid species which will be described in a forthcoming article.

\section{Remarks}

Two of the four species of Odontopyge (re)described by Attems (1896) distinguished themselves by the possession of a peculiar, multi-cusped process on the gonopod telopodite. This process, labelled $c$ on Attems' figures, corresponds to the proximal telomere process (tpp) in the sense of the present paper. The two species in question were $O$. kraepelini, described as new, and a species which Attems identified as O. pardalis (Gerstäcker). He later (Attems 1914) realised that this was not the real pardalis Gerstäcker and offered the replacement name Prionopetalum stuhlmanni Attems, 1914 (pardalis has subsequently been transferred to the genus Calyptomastix Hoffman \& Howell, 2012).

The two species, kraepelini and stuhlmanni, are very similar indeed according to the descriptions and illustrations offered by Attems (1896). The only substantial apparent difference concerns the profile of the gonopod coxa. Attems (1896) provided two gonopod drawings of stuhlmanni (as pardalis), and one of kraepelini. The three drawings are all quite different regarding the gonopod coxa profiles, but this is due to the fact that two of them, the one of kraepelini (Attems' fig. 1) and one of those of stuhlmanni (Attems' fig. 8), are based on gonopods macerated in $\mathrm{KOH}$, whereas his fig. 7 (of stuhlmanni) is based on unmacerated gonopods. Attems' fig. 7 is fully compatible with the present illustrations (Figs 5-6) of specimens from Mang'ula, and side-by-side comparisons of the body and gonopods of Mang'ula specimens with the holotype of stuhlmanni reveal no differences (see Fig. 2 for agreement in body size). The male syntype of kraepelini is devoid of its gonopods, and these are not retrievable elsewhere. I interpret the apparent differences between macerated gonopods of kraepelini (Attems 1896: fig. 1) and stuhlmanni (Attems 1896: fig. 8) as being artificial and possibly due to different durations of the $\mathrm{KOH}$ maceration, and I therefore synonymize the two names.

Knob-like intercalary cuticular micro-scutes were observed in this species (Fig. 5G), cf. Enghoff (2014).

Under the name Prionopetalum stuhlmanni this species is a popular pet millipede; see, e.g., Sigling (2010) and http://www.diplopoda.de/index.php (accessed 29 February 2016).

\section{The status of "Prionopetalum" fasciatum (Attems, 1896)}

Attems (1896) described Odontopyge fasciata from Zanzibar, but later (1914) transferred the species to Prionopetalum without further comment. Brolemann (1920) redescribed the species based on new 
material from Zanzibar and expressed doubts about the genus-level classification of it, suggesting that it might belong in a separate subgenus of Prionopetalum. Kraus (1960), however, accepted the inclusion of fasciata in Prionopetalum. In the most recent treatment of Prionopetalum VandenSpiegel \& Pierrard (2009) discussed fasciata, noticing that it differs from other species of Prionopetalum in several characters: the limbus is almost straight, not serrate; there are no ventral tibial pads on male legs; and the proximal telomeral process ( $t p p$ ) is a simple, rounded lobe. The latter authors reported further new material from Zanzibar as well as from Bagamoyo District, Vula Mountain, Pongwe, on the Tanzanian mainland.

After having examined several specimens from Zanzibar I can now offer a re-classification of this species:

Aquattuor fasciatus (Attems, 1896) comb. nov.

Figs $7-8$

Odontopyge fasciata Attems, 1896: 40.

Prionopetalum fasciatum - Attems 1914: 210. — Brolemann 1920: 123. - Kraus 1960: 86. VandenSpiegel \& Pierrard 2009: 152. — Enghoff et al. 2016.

Aquattuor aff. claudiahempae - Enghoff \& Frederiksen 2015: 19.

\section{Material studied}

Syntypes

TANZANIA: $1 \lesssim$ (+ one extra set of gonopods), 6 우/juvs, Zanzibar, Kibueni (ZMUH).

\section{Other material}

TANZANIA: 3 $\widehat{\partial}$, Zanzibar, Kizimkazi, at foot of mango tree, 17 Jun. 1979, M. Stoltze leg. (ZMUC); 1 đ., Zanzibar, the sultan's palace, 16 Jun. 1979, M. Stoltze leg. (ZMUC).

In addition, Dr. Nesrine Akkari has kindly examined syntypes of $O$. fasciata in NHMW and has placed information and images at my disposal.

\section{Remarks}

The single intact male among the examined syntypes has 53 podous rings (no apodous rings in front of the telson) and a diameter of $1.91 \mathrm{~mm}$. A syntype at NHMW has the same number of rings and a diameter of $1.86 \mathrm{~mm}$. The specimens from Kizimkazi are all broken, the males have maximum body diameters of $1.55-1.62 \mathrm{~mm}$. The male from the sultan's palace has 51 podous rings (no apodous rings in front of the telson) and a diameter of $1.86 \mathrm{~mm}$.

The limbus (Fig. 7A) consists of large, rectangular, easily detached flaps, characteristic of the genus Aquattuor.

The gonopods (Figs 7B-F, 8) are indistinguishable from those of Aquattuor claudiahempae Enghoff \& Frederiksen, 2015 (cf. their fig. 15). Noticeable special similarities include the profile of the apical palette $(p a)$, the well-developed mesobasal lobe $(\mathrm{mbl})$ of the coxal palette, and the partly micro-serrate margin of the telomere (Fig. 7 E, arrow).

The characteristic limbus was not noted by previous authors. Attems (1896) and Brolemann (1920) did not mention the limbus at all. VandenSpiegel \& Pierrard (2009: fig. 1b) illustrated the limbus, but their SEM micrograph only showed an irregularly wavy margin. The large limbus lobes were probably all broken off in the specimens examined by these authors (compare the left part of Fig. 7A with fig 1b 

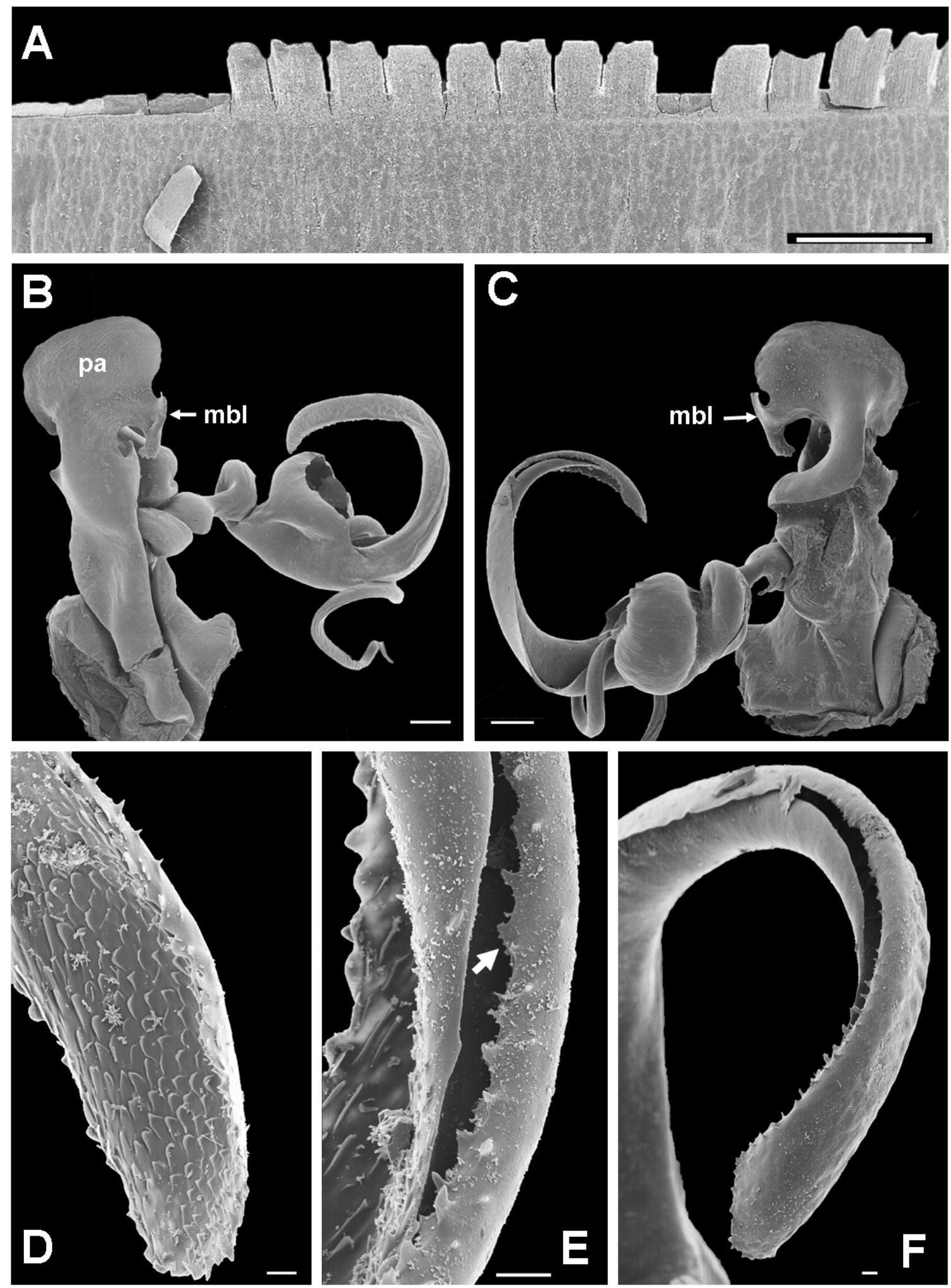

Fig. 7. Aquattuor fasciatus (Attems, 1896) comb. nov., specimen from Zanzibar, Kirimkazi. A. Limbus. B-C. Left gonopod. B. Anterior view. C. Posterior view. D-F. Left telomere. D. Tip, basal-anterior view. E. Subdistal part, posterior view (bold arrow points to a microserrate lobe on the margin). F. Tip, apical-posterior view. Abbreviations: $m b l=$ mesobasal lobe of coxal palette; $p a=$ apical palette of coxa. Scale bars: $\mathrm{A}-\mathrm{C}=0.1 \mathrm{~mm} ; \mathrm{D}-\mathrm{F}=0.01 \mathrm{~mm}$. 
in VandenSpiegel \& Pierrard 2009). In the syntypes from ZMUH the limbus seems to be completely worn off. However, Dr. Nesrine Akkari has kindly provided images based on the syntypes of $O$. fasciata in NHMW which clearly show the Aquattuor type of limbus, as well as confirm the great similarity in gonopod structure between this species and A. claudiahempae (Fig. 8). The gonopods of the intact male syntype (now dissected by me) closely agree with the illustrations in Figs 7-8. The extra set of gonopods among the syntypes very much resembles fig. 6 in Attems (1896), which is based on macerated gonopods, and they were most probably the model for this drawing.

The syntypes of fasciatus as well as the Zanzibar specimens collected by M. Stoltze are very similar to A. claudiahempae Enghoff \& Frederiksen (2015), and it is possible that the latter name should be regarded as a junior synonym of $A$. fasciatus. However, the body diameter of the specimens from Kizimkazi is at the high end, and partly larger, compared to A. claudiahempae from Mt. Kilimanjaro. The two intact specimens from Zanzibar examined here, viz., the intact syntype and the male from the sultan's palace, are definitely much larger. The latter specimens are more similar in size to A. cf. claudiahempae, recorded from the Morogoro Region, Kilosa District, Rubeho Mts by Enghoff \& Frederiksen (2015). Attems (1896) gave the (horizontal) diameter of A. fasciatus as $2 \mathrm{~mm}$. Brolemann (1920) gave 55 podous rings (= "56 segments ... 1 segment apode") and a diameter of $1.70 \mathrm{~mm}$ for an adult male. Whereas " $2 \mathrm{~mm}$ " is much more than any other specimen in this complex, Brolemann's values would fit A. claudiahempae by extrapolation.

The situation is obviously complicated, and for the time being, A. fasciatus and A. claudiahempae are kept as separate species.

\section{A key to the species of Prionopetalum}

This key builds extensively on previous keys provided by Kraus (1960) and VandenSpiegel \& Pierrard (2009). The new species described here is included, but Aquattuor fasciatus is excluded, and P. stuhlmanni is treated as a synonym of P. kraepelini (cf. above). I follow VandenSpiegel \& Pierrard (2009) in not
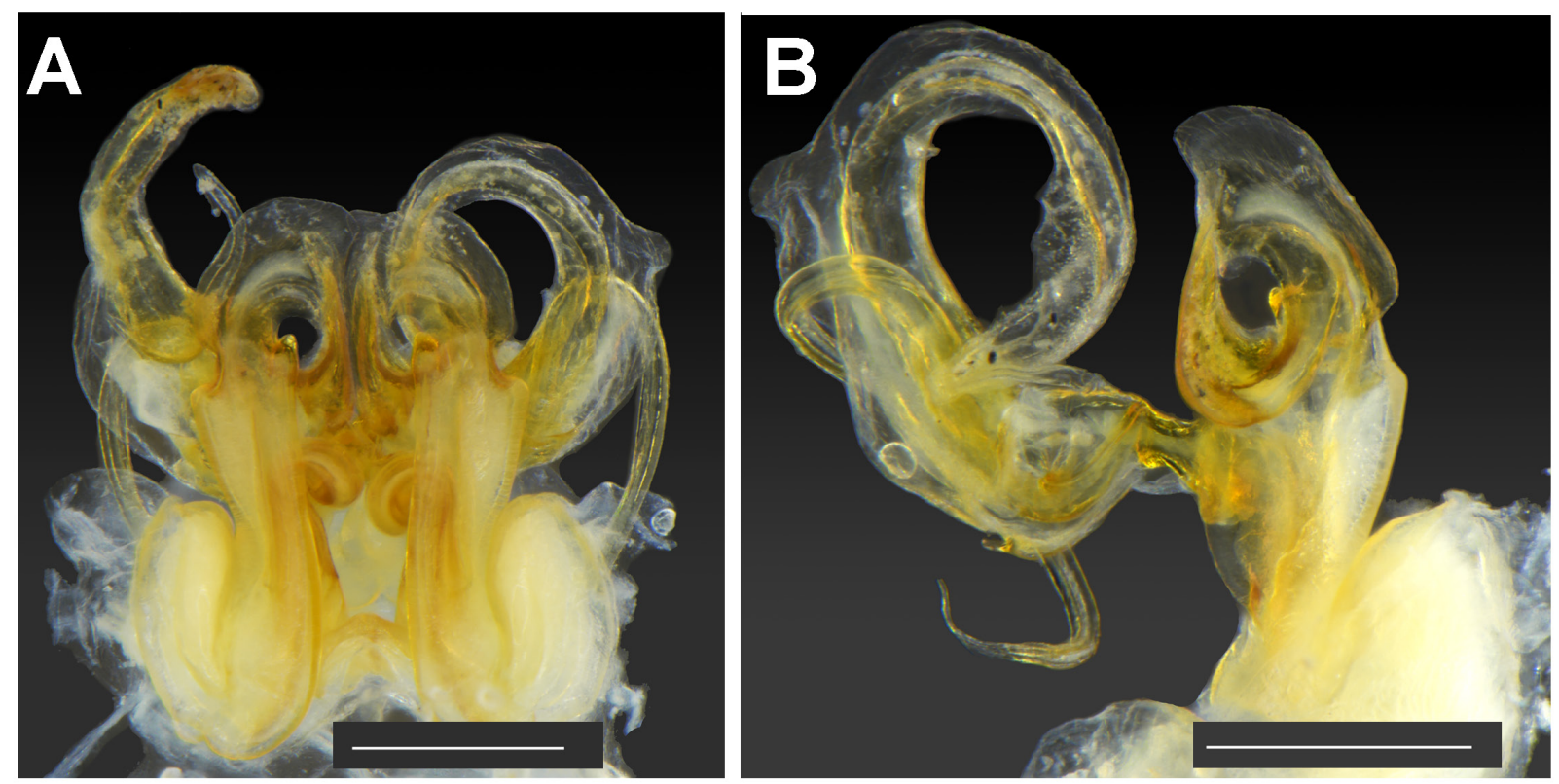

Fig. 8. Aquattuor fasciatus (Attems, 1896) comb. nov., syntype of Odontopyge fasciata (NHMW 2672). A. Gonopods, anterior view. B. Left gonopod, posterior view. Scale bars $=0.5 \mathrm{~mm}$. Photographs: N. Akkari. 
considering Spinotarsus werneri Attems, 1910 as a species of Prionopetalum, although Kraus (1960) suggested such a relationship (but still listed S. werneri under "species incertae sedis").

1. Coxa with a straight, mostly long lateral spine pointing basad, laterobasad or laterad (Fig. 9A-L)

- Coxa different, sometimes with another type of lateral process, but not a straight basad, laterobasad or laterad spine

2. Lateral coxal spine directed laterad, set off by right angles from main coxal margin (Fig. 9A) ......

P. megalacanthum Attems, 1912

- Lateral coxal spine different

3. Lateral coxal spine directed basad, in part overlying main body of coxa (Fig. 9B)

P. frundsbergi (Attems, 1927)

- Lateral coxal spine different

4. Tip of distal telomere process $(t d p)$ divided into two equal branches (Fig. 10A). Gonopod coxa profile as Fig. 9C

P. bifidum VandenSpiegel \& Pierrard, 2009

- Tip of distal telomere process not divided into two equal branches, but one or two small subapical processes may be present

5. Distal telomere process $(t d p)$ ending in three dark spines (Fig. 10B). Gonopod coxa profile as Fig. 9D

P. tricuspis Brolemann, 1920

- Tip of distal telomere process at most with a single accessory process/spine

6. Proximal telomere process (tpp) distally expanded, asymmetrically club-shaped (Fig. 11A-F) ......7

- Proximal telomere process not strongly expanded distally (Fig. 11G-K) .......................................12

7. Distal telomere process $(t d p)$ with a small accessory process (Fig. 10C) …..............................

- Distal telomere process without accessory process (like Fig. 10D) ...........................................

8. Lateral coxal spine relatively short, directed almost basad (Fig. 9E). Proximal telomere process (tpp) moderately asymmetrical (Fig. 11A)

P. aculeatum Attems, 1914

- Lateral coxal spine directed almost laterad (Fig. 8F). Proximal telomere process strongly asymmetrical (Fig. 11B)

P. ndelei VandenSpiegel \& Pierrard, 2009

9. Coxa mesapically rounded (Fig. 9G). Proximal telomere process as in Fig. 11C

P. serratum Attems, 1909

- Coxa mesapically with a spinous projection (Fig. 9H-J, arrows)

10. Distal margins of proximal telomere process (tpp) smooth (Fig. 10D). Gonopod coxa profile as Fig. 9H P. dentigerum Verhoeff, 1941

- Distal margin of proximal telomere process wavy or with a denticle (Fig. 11E-F) .........11

11. Distal margin of proximal telomere process (tpp) wavy (Fig. 11E). Gonopod coxa profile as Fig. 9I

P. tanganjikum Verhoeff, 1941

- Distal margin of proximal telomere process with a single denticle (Fig. 11F, arrow). Gonopod coxa profile as Fig. 9J

P. xerophilum (Carl, 1909) 

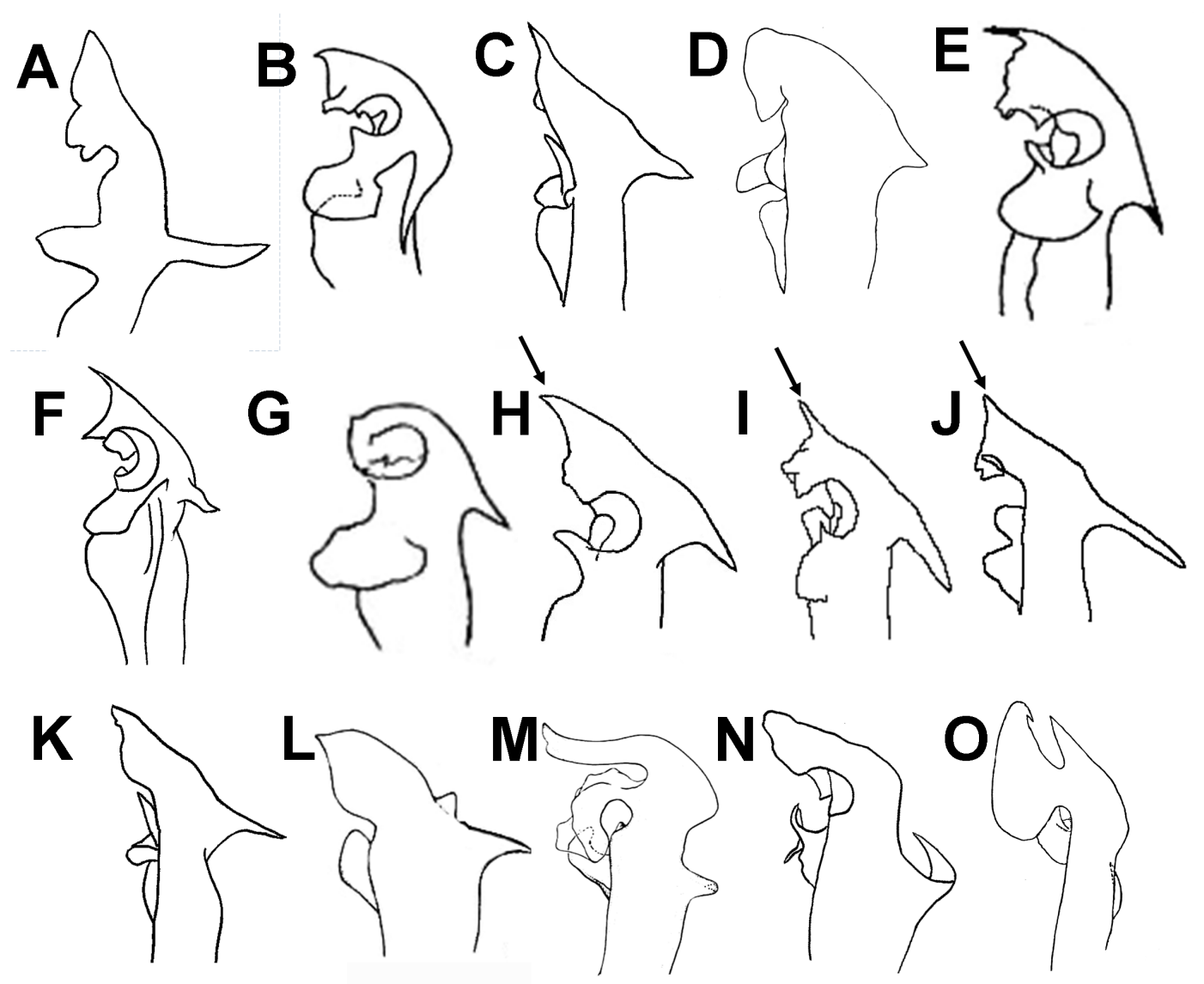

$P(a)$
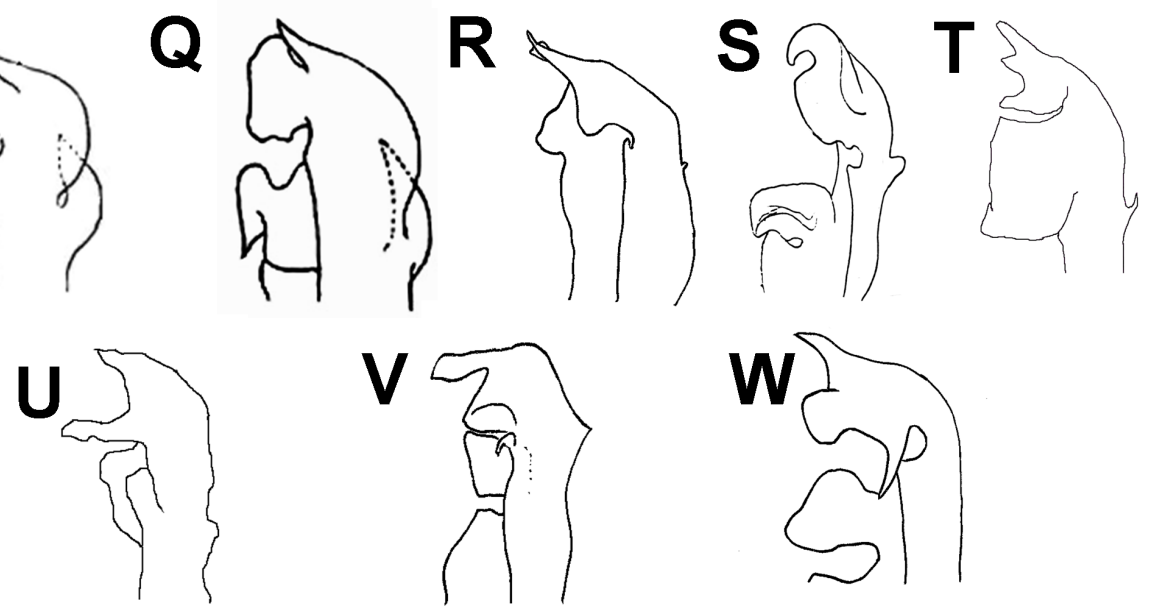

Fig. 9. Prionopetalum spp., outlines of distal part of gonopod coxa. The species appear in the sequence in which they key out in the identification key. A. P. megalacanthum (after a specimen in NHMW). B. P. frundsbergi (based on Kraus 1960). C. P. bifidum (based on VandenSpiegel \& Pierrard 2009). D. P. tricuspis (based on Brolemann 1920). E. P. aculeatum (based on Kraus 1960). F. P. ndelei (based on VandenSpiegel \& Pierrard 2009). G. P. serratum (based on Kraus 1960). H. P. dentigerum (based on Kraus 1960). I. P. tanganjikum (based on Kraus 1960). J. P. xerophilum (based on Kraus 1960). K. P. clarum (based on Kraus 1960). L. P. pulchellum (based on Kraus 1960). M. P. etiennei (based on Demange 1982). N. P. lindi (based on VandenSpiegel \& Pierrard 2009). O. P. coronatum (based on Kraus 1958). P. P. exaratum (based on Kraus 1960). Q. P. cornutum (based on Kraus 1960). R. P. kraepelini (orig.). S. P. glomeratum (based on Attems 1935). T. P. urbicolum (based on Kraus 1960). U. P. suave (based on Kraus 1960). V. P. fryeri (based on Kraus 1960). W. P. asperginis sp. nov. (orig). Not to scale. 
12. Proximal telomere process (tpp) straight, apically rounded (Fig. $11 \mathrm{G})$. Body diameter $5.5 \mathrm{~mm}$. Gonopod coxa profile as Fig. 9K P. clarum (Chamberlin, 1927)

- Proximal telomere process slightly curved, pointed (Fig. 11H). Body diameter $3 \mathrm{~mm}$. Gonopod coxa profile as Fig. 9L

13. Coxa with a strongly curved lateral spine (Fig. 9M-N)

- Lateral coxal spine, if present, not strongly curved

14. Gonopod coxa profile as Fig. 9M. Body diameter $2.5 \mathrm{~mm}$

P. etiennei Damange, 1982

- Gonopod coxa profile as Fig. 9N. Body diameter 3.3-3.8 mm

P. lindi VandenSpiegel \& Pierrard, 2009

15. Lateral coxal spine sizeable, directed apicad and partly overlying main body of coxa. Coxa apically bifid (Fig. 90-Q)

- Coxa at most with a tiny lateral spine or bump (Fig. 9R-W)

16. Both apical branches of coxa pointed, the mesal branch hook-like (Fig. 9O)

..P. coronatum Kraus, 1958

- Mesal-apical branch of coxa not pointed (Fig. 9P-Q)

17. Gonopod coxa profile as Fig. 9P

P. exaratum (Attems, 1938)

- Gonopod coxa profile as Fig. 9Q

P. cornutum Kraus, 1958

18. Proximal telomere process (tpp) with several lobes along one side (Fig. 11I). Gonopod coxa profile as Fig. 9R

P. kraepelini (Attems, 1896)

- Proximal telomere process at most with a single lateral lobe (Fig. 11J-K)

19. Coxal apex hook-like (Fig. 9S). Body diameter $2.5 \mathrm{~mm}$

P. glomeratum Attems, 1935

- Coxal apex not hook-like (Fig. 9T-W). Body diameter 4.4-5 mm

20. Coxal apex with three mesad processes (Fig. 9T)

P. urbicolum (Carl, 1909)

- Coxal apex with two mesad processes (Fig. 9U-W)
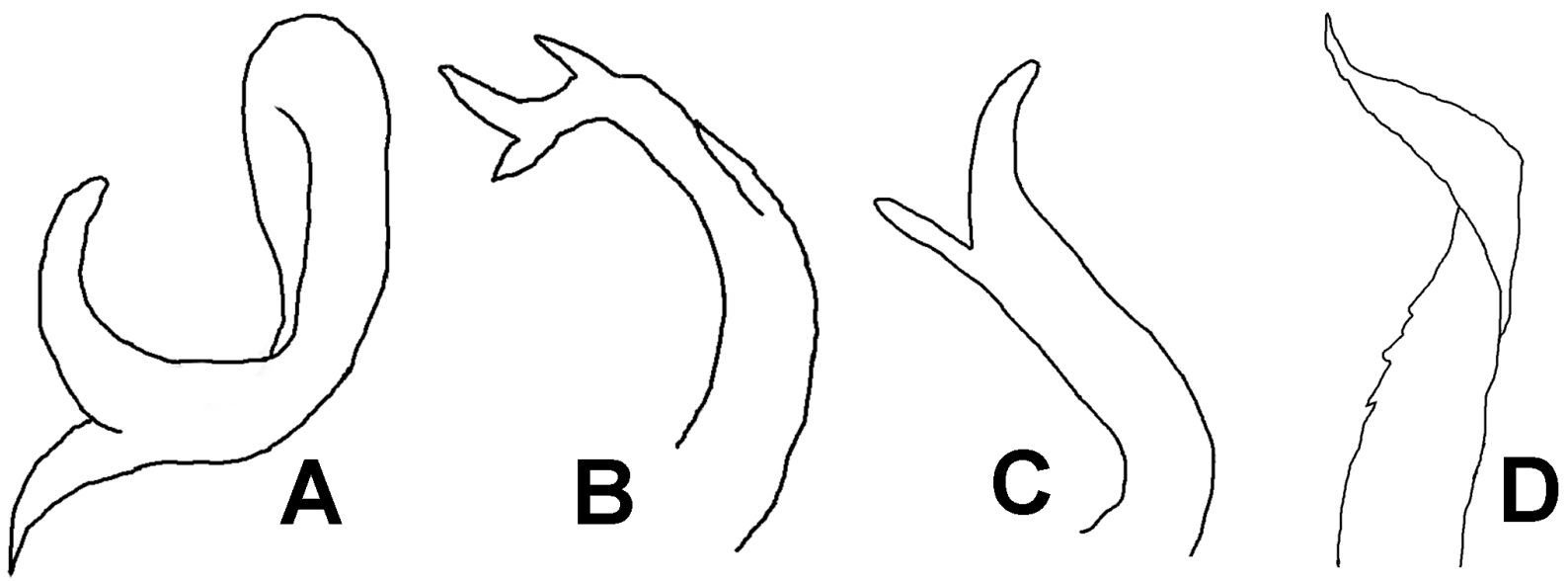

Fig. 10. Prionopetalum spp., outlines of distal telomere process $(t d p)$. A. P. bifidum (based on VandenSpiegel \& Pierrard 2009). B. P. tricuspis (based on VandenSpiegel \& Pierrard 2009). C. P. aculeatum (based on Attems 1914). D. P. asperginis sp. nov. (orig.). Not to scale. 
21. Both mesad processes of coxal apex pointed (Fig. 9U)

P. suave (Gerstäcker, 1873)

- Subapical mesad process of coxal apex rounded (Fig. 9V-W)

22. Gonopod coxa profile as Fig. 8V. Solenomere with a short accessory branch at $c .2 / 3$ of its length. Proximal telomere process as Fig. 11J.

P. fryeri (Turk, 1956)

- Gonopod coxa profile as Fig. 8W. Solenomere without an accessory branch. Proximal telomere process as Fig. $11 \mathrm{~K}$

P. asperginis sp. nov.

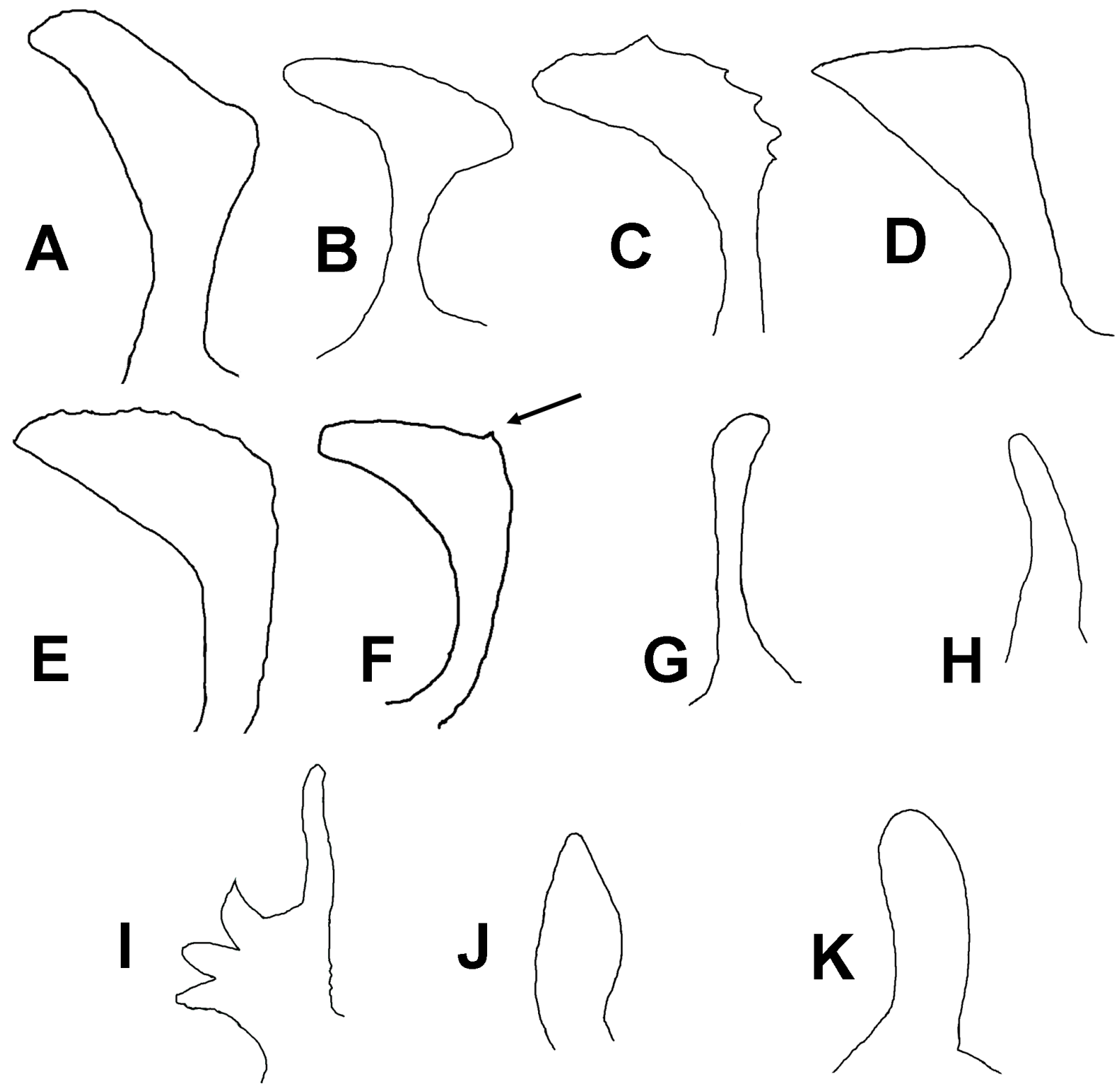

Fig. 11. Prionopetalum spp., outlines of proximal telomere process (tpp). A. P. aculeatum (based on Attems 1914). B. P. ndelei (based on VandenSpiegel \& Pierrard 2009). C. P. serratum (based on Attems 1909). D. P. dentigerum (based on Kraus 1960). E. P. tanganjikum (based on Kraus 1960). F. P. xerophilum (based on Kraus 1960). G. P. clarum (based on Kraus 1960). H. P. pulchellum (based on Kraus 1960). I. P. kraepelini (orig.). J. P. fryeri (based on Kraus 1960). K. P. asperginis sp. nov. (orig.). Not to scale. 


\section{Discussion}

Among the Odontopygidae from the Udzungwa Mts studied so far, species of Prionopetalum occur at the lowest altitudes: $300-339 \mathrm{~m}$ asl for P. kraepelini and 550-750 m asl for P. asperginis sp. nov. In comparison, the altitudinal span of the Udzungwa endemic Chaleponcus dabagaensis group is 1390-2100 m asl (Enghoff 2014), of Udzungwa Aquattuor species 750-1800 (1850) m asl (Enghoff \& Frederiksen 2015), and of Udungwa Geotypodon species 1145-1500 m asl (Enghoff 2016). This is in line with the general tendency of Prionopetalum species to occur in savanna-like habitats where some of them even have synanthropic tendencies: P. urbicolum, true to its name, has often been found in Dar-es-Salaam, and P. frundbergi has been collected in Mombasa and Tanga in Kenya (Enghoff et al. 2016). Some Prionopetalum species are even known as pests on various crops, including $P$. etiennei on potato, African eggplant and okra in Senegal (Demange 1982; Etienne et al. 1992) and Prionopetalum sp. (possibly P. xerophilum) on sweet potato in Uganda (Ebregt et al. 2005).

It is worth noting that P. kraepelini, the most 'lowlandish' Udzungwa odontopygid known so far, is the only species among the Udzungwa odontopygids which (according to present knowledge) is not endemic to this mountain range.

\section{Acknowledgements}

Thanks are due to the Tanzanian authorities that granted permits for collecting in the Udzungwa Mountains, as well as to my colleagues Thomas Pape and Nikolaj Scharff for providing most of the specimens, to Judith Winston and her colleagues at VMNH for access to specimens in that museum, to Matthias Glaubrecht and Thure Dalsgaard for access to specimens in ZMUH, to Nesrine Akkari for great help during and after my visit to NHMW, including provision of original images, and to Hans Reip for access to old literature.

\section{References}

Attems C.G. 1896. Beschreibung der von Dr. Stuhlmann in Ost-Afrika gesammelten Myriopoden. Jahrbuch der hamburgischen wissenschaftlichen Anstalten 13 (Supplement): 23-42. Available from: http://biodiversitylibrary.org/page/28745426 [accessed 15 Jun. 2016]

Attems C.G. 1909. Myriopoda. Wissenschaftliche Ergebnisse der schwedischen zoologischen Expedition nach dem Kilimandjaro, dem Meru und den umgebenden Massaisteppen Deutsch-Ostafrikas 1905-1906 3 (19): 1-64. Available from: http://biodiversitylibrary.org/page/1410223 [accessed 15 Jun. 2016]

Attems C.G. 1912. Myriopoden. Wissenschaftliche Ergebnisse der deutschen Zentral-Afrika-Expedition 1907-1908 unter Führung Adolf Friedrichs, Herzog zu Mecklenburg, 4 (Zoologie): 297-324. Available from: http://biodiversitylibrary.org/page/965153 [accessed 15 Jun. 2016]

Attems C.G. 1914. Afrikanische Spirostreptiden nebst Überblick über die Spirostreptiden orbis terrarum. Zoologica Stuttgart 65-66: 1-233.

Attems C.G. 1935. Diplopoden des Belgischen Congo (Schluss). Revue de Zoologie et de Botanique Africaines 26: 327-396.

Attems C.G. 1938. Diplopoden des Belgischen Congo. Polydesmoidea, 2. Nachtrag und Spirostreptoidea, 1. Nachtrag. Revue de Zoologie et de Botanique Africaines 31: 225-313.

Brolemann H.W. 1920. Myriapodes. In: Alluaud Ch. (ed.) Voyage de Ch. Alluaud et R. Jeannel en Afrique Orientale 1911-1912. Résultats Scientifiques. Myriapoda 3: 49-298. A. Schultz, Paris.

Carl J. 1909. Diplopoden. Reise von Dr. J. Carl im nördlichen central-afrikanischen Seengebiet. Revue Suisse de Zoologie 17: 281-365. Available from: http://biodiversitylibrary.org/page/10709191 [accessed 15 Jun. 2016] 
Chamberlin R.V. 1927. The Chilopoda and Diplopoda collected by the American Museum of Natural History Congo Expedition (1909-1915), with notes on some other African species. Bulletin of the American Museum of Natural History 57 (4): 177-249.

Demange J.-M. 1982. Contribution à la connaissance des Myriapodes du Sénégal: Diplopodes nuisibles aux cultures et Chilopodes. Bulletin du Muséum national d'Histoire naturelle, 4e Série 4, Section A 3-4: $445-453$.

Ebregt E., Struik P.C., Odongo B. \& Abidin P.E. 2005. Pest damage in sweet potato, groundnut and maize in north-eastern Uganda with special reference to damage by millipedes (Diplopoda). NJAS Wageningen Journal of Life Sciences 53 (1): 49-69. http://dx.doi.org/10.1016/S1573-5214(05)80010-7

Enghoff H. 2011. East African giant millipedes of the tribe Pachybolini (Diplopoda, Spirobolida, Pachybolidae). Zootaxa 2753: 1-41.

Enghoff H. 2014. A mountain of millipedes I: An endemic species-group of the genus Chaleponcus Attems, 1914, from the Udzungwa Mountains, Tanzania (Diplopoda, Spirostreptida, Odontopygidae). European Journal of Taxonomy 100: 1-75. http://dx.doi.org/10.5852/ejt.2014.100

Enghoff H. 2016. A mountain of millipedes III: A new genus for three new species from the Udzungwa mountains and surroundings, Tanzania, as well as several 'orphaned' species previously assigned to Odontopyge Brandt, 1841 (Diplopoda, Spirostreptida, Odontopygidae). European Journal of Taxonomy 177: 1-19. http://dx.doi.org/10.5852/ejt.2016.177

Enghoff H. \& Frederiksen S.B. 2015. A mountain of millipedes II: The genus Aquattuor Frederiksen, 2013 - five new species from the Udzungwa Mountains and one from Mt. Kilimanjaro, Tanzania (Diplopoda, Spirostreptida, Odontopygidae). European Journal of Taxonomy 150: 1-25. http://dx.doi. org/10.5852/ejt.2015.150

Enghoff H., Hoffman R.L. \& Howell K.M. 2016. Checklist of the millipedes (Diplopoda) of Tanzania. Journal of East African Natural History 105: 51-113. http://dx.doi.org/10.2982/028.105.0103

Etienne J., Delvare G. \& Aberlenc H.P. 1992. Contribution à la connaissance de l'arthropodofaune associée aux cultures de Casamace (Sénégal). Bollettino di Zoologia agraria e di Bachicoltura, Series II 24 (2): 159-193.

Hoffman R.L. \& Howell K.M. 2012. A new genus of odontopygid millipeds from Tanzania (Diplopoda: Spirostreptida: Odontopygidae). Journal of East African Natural History 101 (1): 67-72. http://dx.doi. org/10.2982/028.101.0104

IUCN SSC Amphibian Specialist Group. 2015. Nectophrynoides asperginis. The IUCN Red List of Threatened Species 2015: e.T54837A16935685. http://dx.doi.org/10.2305/IUCN.UK.2015-2.RLTS. T54837A16935685.en

Kraus O. 1958. Myriapoda (Chilopoda, Diplopoda). Exploration du Parc National de l'Upemba (Mission G. de Witte) 54 (1): 1-67.

Kraus O. 1960. Äthiopische Diplopoden I. Monographie der Odontopygidae-Odontopyginae (Diplopoda, Spirostreptoidea). Annalen van het Koninklijk Museum van Belgisch-Congo 82: 1-207.

Kraus O. 1966. Phylogenie, Chorologie und Systematik der Odontopygoideen (Diplopoda, Spirostreptomorpha). Abhandlungen der senckenbergischen naturforschenden Gesellschaft 512: 1-143.

Marshall A.R., Jørgensbye H.I.O., Rovero F., Platts P.L., White P.C.L. \& Lovett J.C. 2010. The speciesarea relationship and confounding variables in a threatened monkey community. American Journal of Primatology 72: 325-336. http://dx.doi.org/10.1002/ajp.20787 
ENGHOFF H., Prionopetalum millipedes from the Udzungwa Mts

Reboleira A.S.P.S., Hosseini M.J.M., Sadeghi S. \& Enghoff H. 2015. Highly disjunct and highly infected millipedes - a new cave-dwelling species of Chiraziulus (Diplopoda: Spirostreptida: Cambalidae) from Iran and notes on Laboulbeniales ectoparasites. European Journal of Taxonomy 146: 1-18. http://dx.doi. org/10.5852/ejt.2015.146

Sigling S. 2010. PraxisRatgeber Tausendfüsser. Chimaira, Frankfurt am Main.

Turk F.A.1956. Millepedes from Nyasaland: a new species and a rediscovered one. Annals and Magazine of Natural History, $12^{\text {th }}$ Series 9: 737-741. http://dx.doi.org/10.1080/00222935608655888

VandenSpiegel D. \& Pierrard G. 2009. Révision du genre Prionopetalum (Odontopygidae, Diplopoda) et descriptions de nouvelles espèces d'Afrique de l'Est. Journal of Afrotropical Zoology 5: 149-163.

Verhoeff K.W. 1941. Studien an äthiopischen Diplopoden. Jenaische Zeitschrift für Naturwissenschaft 73: 231-274.

Zilihona I., Heinonen J. \& Nummelin M. 1998. Arthropod diversity and abundance along the Kihansi Gorge (Kihansi River) in the southern Udzungwa Mountains, Tanzania. Journal of East African Natural History 87 (1): 233-240. http://dx.doi.org/10.2982/0012-8317(1998)87[233:ADAAAT]2.0.CO;2

\section{Correction to Enghoff (2016)}

On p. 17 of the previous article in the "A mountain of millipedes" series (Enghoff 2016), the reference to Dieudonné (2016) should instead be to Ntashavu (2016).

Manuscript received: 3 February 2016

Manuscript accepted: 4 March 2016

Published on:22 July 2016

Topic editor: Rudy Jocqué

Desk editor: Danny Eibye-Jacobsen

Printed versions of all papers are also deposited in the libraries of the institutes that are members of the EJT consortium: Muséum national d'Histoire naturelle, Paris, France; Botanic Garden Meise, Belgium; Royal Museum for Central Africa, Tervuren, Belgium; Natural History Museum, London, United Kingdom; Royal Belgian Institute of Natural Sciences, Brussels, Belgium; Natural History Museum of Denmark, Copenhagen, Denmark; Naturalis Biodiversity Center, Leiden, the Netherlands. 